\title{
Synthesis the Ni substituted Mn ferrites and Study the applications of ferrite
}

\author{
Sharifa Nasrin ${ }^{1}$, Md. D. Rahaman ${ }^{2}$, A. K. M. Akther Hossain ${ }^{3}$ \\ ${ }^{1}$ Directorate of Secondary and Higher Education, Dhaka, Bangladesh. \\ ${ }^{2}$ Department of Physics, University of Dhaka, Bangladesh. \\ ${ }^{3}$ Department of Physics, Bangladesh University of Engineering and Technology, Dhaka, Bangladesh.
}

\begin{abstract}
With improved initial permeability and extremely low relative loss factor (RLF) of Nanocrystalline Ni-Cu ferrites were synthesized by combustion technique by doping excess amount of $\mathrm{Mn}$ at different sintering temperatures. Ferrites are ceramic magnetic oxides materials. It shows the property of electrical insulator and magnetic conductor with large number of applications in various fields. Structural characteristics were measures from the X-ray diffraction (XRD) patterns. It shows formation of pure single-phase cubic spinel structure with Nanocrystalline and good chemical homogeneity. From these data lattice constant was calculated. By the doping of $\mathrm{Mn}$ content it is found that lattice constant increases and these compositions obey the Vegard's law. From this study it was found that at the increasing of $\mathrm{Mn}$ content highly dense with lower porous and bigger grain of ferrite increases its magnetic and electric properties. High magnetization, high permeability, high quality factor, high mechanical stability, low loss factor were found in magnetic measurement.
\end{abstract}

Keywords: X-ray diffraction, Nanocrystalline, combustion technique, ferrites, lattice constant, grain size, permeability, DC magnetization

\section{Introduction}

Ferrites are widely used in many electronic devices because of their high magnetic permeability and low magnetic losses. The nano-sized magnetic particles have different properties from the corresponding bulk materials due to their reduced size and effect of magnetic interaction between particles. Spinel type $\mathrm{M}^{2+} \mathrm{M}^{3+}{ }_{2} \mathrm{O}_{4}$ is interesting because of their diverse applications [1]. The spinel structure is essentially cubic, with the $\mathrm{O}^{2-}$ forming f.c.c lattice. The cations (usually metals) occupy $1 / 8$ of the tetrahedral sites and $1 / 2$ of the octahedral sites and there are $32 \mathrm{O}^{2-}$ in a unit cell. They are preferred because of their high permeability and saturation magnetization in the radio- frequency (RF) region, high electrical resistivity, mechanical hardness and chemical stability [2]. The possibility of preparing ferrites in the form of nanoparticles has opened a new and exciting research field, with revolutionary applications not only in the electronic technology but also in the field of biotechnology [3]. Important advances of nanotechnology are the diagnosis of diseases i.e. early cancer cells. The properties of ferrites are highly sensitive to the method of preparation, additives, doping, calcinations and sintering temperatures. Combustion method is a novel method for preparation of fine nano sized particles of ferrites, makes use of the strong exothermic reaction between metal nitrate and fuel. Compared with other methods, the combustion synthesis exhibits many advantages: Nanocrystalline synthesizing, pure and single phase ferrite formation at low temperature, a good chemical homogeneity, simple equipment and preparation process, inexpensive raw materials, fast production rate, etc.[4]. Cupper ferrite among this extensive class of compounds has been investigated because of its interesting crystallographic and electrical properties [5]. Several investigators have focused their attention on $\mathrm{Ni}-\mathrm{Cu}$ mixed spinel ferrite because $\mathrm{Cu}$ containing ferrites have interesting electrical and magnetic properties [6-7]. In the present research, properties of $\mathrm{Mn}$ doped $\mathrm{Ni}-\mathrm{Cu}$ ferrites was investigated prepared by combustion technique. To investigate the effect of the sintering temperature was also varied from 1150 to $1300^{\circ} \mathrm{C}$. Sintering temperature and calcinations were important factors for fabrication of the composition. This study tried to get the high density, high purified, larger grain size of the compositions. The results are greatly affecting as this types of composition has high permeability, high RQF, high magnetization and low relative loss factor.

\section{Experimental Details}

By combustion method compositions were prepared for Nanocrystalline formation. The raw materials were $\mathrm{Ni}\left(\mathrm{NO}_{3}\right)_{2} \cdot 6 \mathrm{H}_{2} \mathrm{O}, \mathrm{MnCl}_{2} \cdot 4 \mathrm{H}_{2} \mathrm{O}, \mathrm{Cu}\left(\mathrm{NO}_{3}\right)_{2} \cdot 3 \mathrm{H}_{2} \mathrm{O}$ and $\mathrm{Fe}\left(\mathrm{NO}_{3}\right)_{3} \cdot 9 \mathrm{H}_{2} \mathrm{O}$. For synthesis the spinal ferrite this raw materials were weighted, stoichometric amount of these raw materials were mixed thoroughly in ethanol in a glass beaker. It dried at $70-80^{\circ} \mathrm{C}$ by placed in a constant temperature bath, then these were ground with a pestle in an agate mortar. Dried powders then placed in a alumina crucible calcined at $700^{\circ} \mathrm{C}$ for 5 hours in a furnace.

\footnotetext{
* Corresponding Author: Sharifa Nasrin,

E-mail: sharifa_labiba@yahoo.com
} 
The fine nano-sized powders were precipitated after combustion was completed. The calcined mixed powder pressed into small disks, i.e. Pellet and toroid-shaped samples were prepared with a polyvinyl alcohol (PVA) as a binder. These are sintered for $6 \mathrm{~h}$ at various temperatures (1150$1250^{\circ} \mathrm{C}$ ) in air. In the sintering process, at the sintering temperatures $1300^{\circ} \mathrm{C}$ when $\mathrm{Mn}$ content, $\mathrm{x}=0.35$ was doped, this composition was melted. The structural characterization was carried out with an X-ray diffractometer with $\mathrm{Cu}-\mathrm{Ka}$ radiation. Average grain sizes of the samples were determined from optical micrographs obtained by optical microscope. Grain sizes are calculated by linear intercept technique. The frequency dependent complex permeability spectra were investigated at room temperature and dielectric measurement was taken using impedance analyzer (Model no. $65120 \mathrm{~B})$ in the frequency range $100 \mathrm{~Hz}-120 \mathrm{MHz}$ at different sintering temperatures $\left(1150-1250^{\circ} \mathrm{C}\right)$. The DC magnetization measurements were made using the SQUID magnetometer (MPMS-5S; Quantum design co. Ltd.). The composition $\mathrm{Ni}_{0.50} \mathrm{Cu}_{0.50} \mathrm{Fe}_{2} \mathrm{O}_{4}$ was first prepared and then $\mathrm{Mn}$ content, $\mathrm{x}=0.35$ was doped in this composition. The lattice parameter, ' $a$ ', was calculated using the values of $d$-spacing. The lattice parameters were calculated by the following relation,

$$
a=d \sqrt{h^{2}+k^{2}+l^{2}}
$$

The values of lattice parameter ' $a$ ' obtained from each crystal plane are plotted against $F(\theta)$, NelsonRiley function, here

$F(\theta)=1 / 2\left[\cos ^{2} \theta / \sin \theta+\cos ^{2} \theta / \theta\right]$, where $\theta$ is the Bragg's angle. Extrapolation of these lines to $F(\theta)=$ 0 i.e. $\theta=90^{\circ}$, the values of lattice constants were calculated. The mean ionic radius of the variant ions for compositions are written as

$$
r_{\text {(variant) }}=(0.50-\mathrm{x}) r_{N i}+x r_{M n}
$$

Theoretical density, bulk density and porosity of the compositions are written as the formula respectively.

$$
\begin{aligned}
& \rho_{x-r a y}=\frac{8 M}{N_{A} a_{o}^{3}} \mathrm{~kg} / \mathrm{m}^{3} \quad \rho_{B}=M_{A} / V \\
& P=\left\lfloor 100\left(\rho_{x-r a y}-\rho_{B}\right) / \rho_{x-r a y}\right] \%
\end{aligned}
$$

Real part of complex permeability are calculated by

$$
\begin{aligned}
& \mu_{i}^{\prime}=L_{s} / L_{o} \text { and } \mu_{i}^{\prime \prime}=\mu_{i}^{\prime} \tan \delta \\
& L_{o}=\mu_{o} N^{2} S / \pi \bar{d}, N=4 \\
& S=d h, d=\frac{d_{o}-d_{i}}{2}, Q=\frac{\mu_{i}^{\prime}}{\tan \delta}
\end{aligned}
$$

For dielectric measurement silver paste was coated on plate samples.

\section{Results and Discussion}

\subsection{X-ray diffraction}

The XRD graph for the ferrite compositions $\mathrm{Ni}_{0.50} \mathrm{Cu}_{0.50} \mathrm{Fe}_{2} \mathrm{O}_{4}$ and $\mathrm{Ni}_{0.15} \mathrm{Mn}_{0.35} \mathrm{Cu}_{0.50} \mathrm{Fe}_{2} \mathrm{O}_{4}$ are shown in Fig.1. The $\mathrm{X}$-ray diffraction pattern of $\mathrm{Ni}_{0.50} \mathrm{Cu}_{0.50} \mathrm{Fe}_{2} \mathrm{O}_{4}$ with a lattice constant 8.363667 while $\mathrm{Ni}_{0.15} \mathrm{Mn}_{0.35} \mathrm{Cu}_{0.50} \mathrm{Fe}_{2} \mathrm{O}_{4}$ has lattice constant 8.417762 indicate that the samples have cubic spinel structure. The diffraction peaks have been indexed to (111), (220), (311), (222), (400), (422), (511), and (440) and these peaks comply with the reported value [8]. There is no other phase than spinal phase in the patterns.

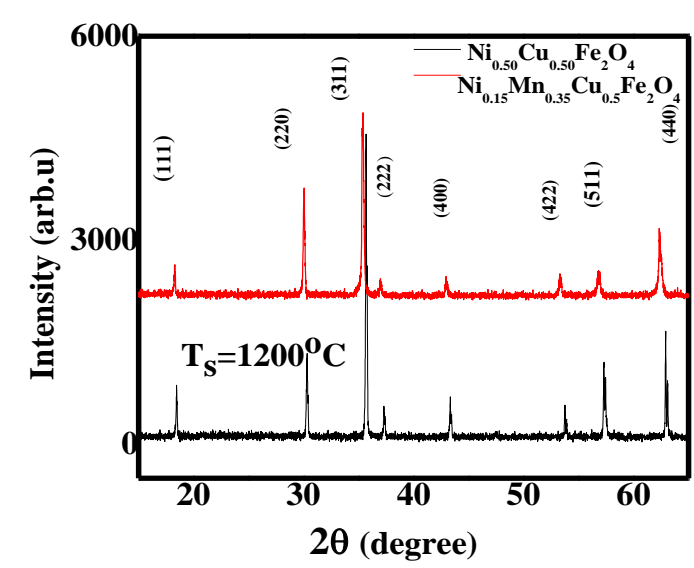

Fig. 1. The $X$-ray diffraction patterns for $\mathrm{Ni}_{0.50} \mathrm{Cu}_{0.50}$ $\mathrm{Fe}_{2} \mathrm{O}_{4}$ and $\mathrm{Ni}_{0.15} \mathrm{Mn}_{0.35} \mathrm{Cu}_{0.50} \mathrm{Fe}_{2} \mathrm{O}_{4}$ ferrites.

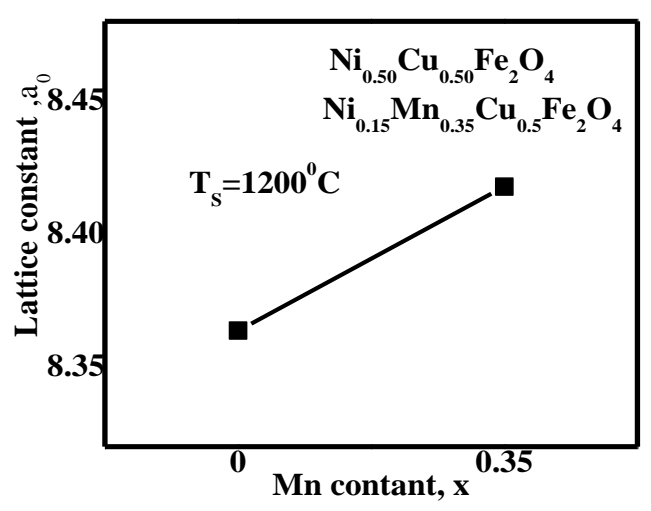

Fig. 2. Variation of lattice constant for $\mathrm{Ni}_{0.50} \mathrm{Cu}_{0.50}-$ $\mathrm{Fe}_{2} \mathrm{O}_{4}$ ferrite doping of $\mathrm{Mn}$ content.

\subsection{Lattice constant}

The lattice constant, $a_{0}$, increases from 8.363667 to 8.417762 with doping of $\mathrm{Mn}$ content shown in Fig. 2. Lattice constant increase with Mn content, indicates that the compositions obey the Vegard's law. The ionic size increases as the substituted ion is learger. The ionic radius of $\mathrm{Mn}^{2+}(0.89 \AA)$ is greater than that of $\mathrm{Ni}^{2+}(0.77 \AA)$ [9]. 


\subsection{Density and porosity}

Variation of density with $\mathrm{Mn}$ content for $\mathrm{Ni}_{0.50} \mathrm{Cu}_{0.50} \mathrm{Fe}_{2} \mathrm{O}_{4}$ and $\mathrm{Ni}_{0.15} \mathrm{Mn}_{0.35} \mathrm{Cu}_{0.50} \mathrm{Fe}_{2} \mathrm{O}_{4}$ ferrite sintered at different temperatures are shown in Fig. 3. It is found that doping of Mn content density increases. And also found at the increases of sintering temperature from 1150 to $1200^{\circ} \mathrm{C}$, the sintered density was already sufficiently high and it decreased as the sintering temperature increased above $1200^{\circ} \mathrm{C}$. The bulk density and porosity with $\mathrm{Mn}$ content for $\mathrm{Ni}_{0.50} \mathrm{Cu}_{0.50} \mathrm{Fe}_{2} \mathrm{O}_{4}$ and $\mathrm{Ni}_{0.15} \mathrm{Mn}_{0.35} \mathrm{Cu}_{0.50} \mathrm{Fe}_{2} \mathrm{O}_{4}$ ferrite at sintering temperature $1200^{\circ} \mathrm{C}$ are shown in Fig. 4. Here porosity follows the opposite trend of bulk density.

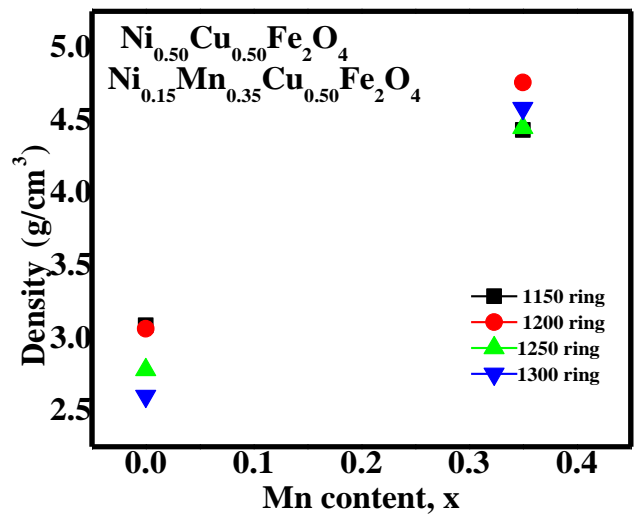

Fig. 3. Density vs $\mathrm{Mn}$ content for $\mathrm{Ni}_{0.50} \mathrm{Cu}_{0.50} \mathrm{Fe}_{2} \mathrm{O}_{4}$ and $\mathrm{Ni}_{0.15} \mathrm{Mn}_{0.35} \mathrm{Cu}_{0.50} \mathrm{Fe}_{2} \mathrm{O}_{4}$ ferrite at different sintering temperatures.

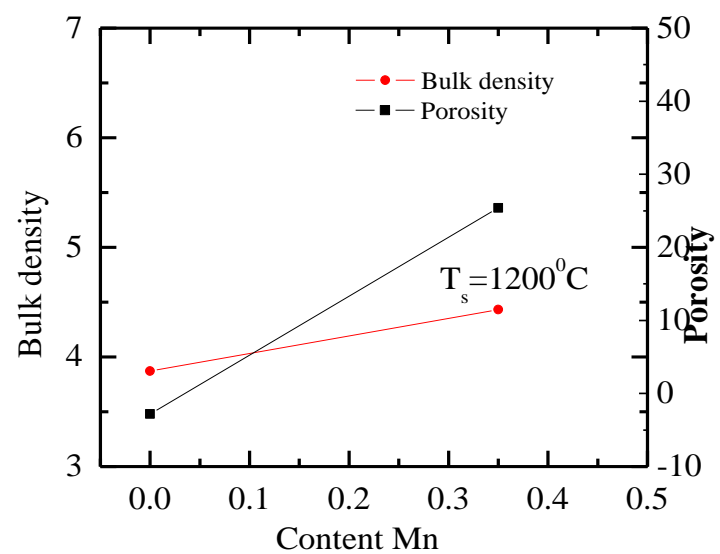

Fig. 4. Density and porosity with $\mathrm{Mn}$ content for $\mathrm{Ni}_{0.50} \mathrm{Cu}_{0.50} \mathrm{Fe}_{2} \mathrm{O}_{4}$ and $\mathrm{Ni}_{0.15} \mathrm{Mn}_{0.35} \mathrm{Cu}_{0.50} \mathrm{Fe}_{2} \mathrm{O}_{4}$ ferrite at sintering at temperature $1200^{\circ} \mathrm{C}$.

\section{Microstructure}

In microstructural analysis, measure the grain size of the sintered samples. Microstructural control is prepared a high dense body and fine grain structure. The optical micrographs for $\mathrm{Ni}_{0.50} \mathrm{Cu}_{0.50} \mathrm{Fe}_{2} \mathrm{O}_{4}$ and $\mathrm{Ni}_{0.15} \mathrm{Mn}_{0.35} \mathrm{Cu}_{0.50} \mathrm{Fe}_{2} \mathrm{O}_{4}$ ferrite sintered at $1150^{\circ} \mathrm{C}$ and $1200^{\circ} \mathrm{C}$ are shown in Fig. 5(a, b). Average grain diameters of the samples are determined from optical micrographs by linear intercept technique [10]. The grain diameter and the types of grain growth of the samples, influence the magnetic and electrical properties of the samples. The microstructural analysis shows that at the doping of $\mathrm{Mn}$ average grain size is very large at sintering temperature $1200^{\circ} \mathrm{C}$, as the melting temperature of $\mathrm{Mn}\left(1245^{\circ} \mathrm{C}\right)$ is lower than the melting temperature of $\mathrm{Ni}\left(1453^{\circ} \mathrm{C}\right)$. The microstructural study also shows that at the increases of sintering temperature 1150 to $1200^{\circ} \mathrm{C}$ grain sizes increases.
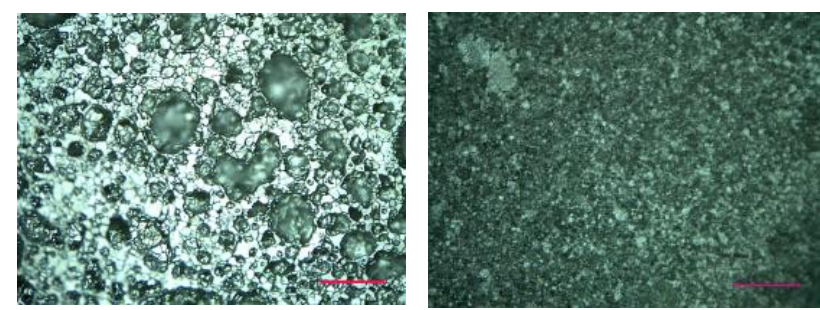

Fig. 5(a). The optical micrographs for $\mathrm{Ni}_{0.50} \mathrm{Cu}_{0.50}$ $\mathrm{Fe}_{2} \mathrm{O}_{4}$ and $\mathrm{Ni}_{0.15} \mathrm{Mn}_{0.35} \mathrm{Cu}_{0.50} \mathrm{Fe}_{2} \mathrm{O}_{4}$ ferrite sintered at $1150^{\circ} \mathrm{C}$.
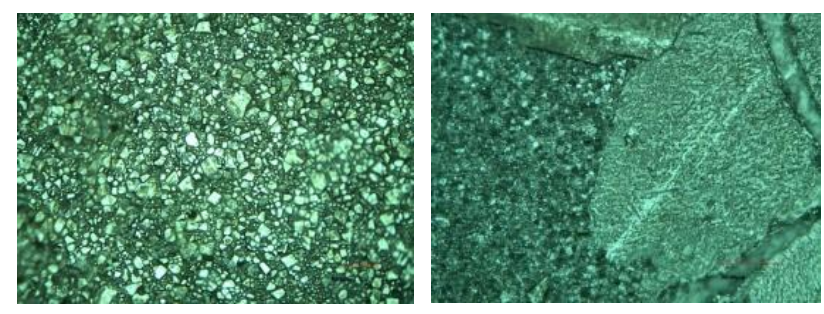

Fig.5(b). The optical micrographs for $\mathrm{Ni}_{0.50} \mathrm{Cu}_{0.50}$ $\mathrm{Fe}_{2} \mathrm{O}_{4}$ and $\mathrm{Ni}_{0.15} \mathrm{Mn}_{0.35} \mathrm{Cu}_{0.50} \mathrm{Fe}_{2} \mathrm{O}_{4}$ ferrite sintered at $1200^{\circ} \mathrm{C}$.

\section{Magnetization}

Magnetic parameters are obtained from the magnetization data. Fig. 6(a) shows magnetization vs magnetic field at room temperature. It was observed that magnetization of the samples increases with increasing the applied magnetic field up to $0.71 \times 10^{5}(\mathrm{~A} / \mathrm{m})$. Beyond this field we find that magnetization increases slowly and finally saturation occurs. The saturation magnetization, $M_{s}$, vs of $M n$ content is shown in Fig. 6(a). The $M_{s}$ increases with increase of $\mathrm{Mn}$ content from 1.13x $10^{5}$ to $2.51 \times 10^{5} \mathrm{~A} / \mathrm{m}$. The number of Bohr magneton, $\mathrm{n}\left(\mu_{\mathrm{B}}\right)$ shown in Fig. $6(\mathrm{~b})$ is calculated using the relation,

$$
n_{B}=\frac{M M_{s}}{N_{A} \mu_{B}}
$$

where $M$ is the molecular weight, $M_{s}$, saturation magnetization, $N_{A}$, Avogadro's number and $\mu_{B}$, the Bohr magneton. The variation in saturation 
magnetization can be explained by the cations distribution. Also on the exchange interaction between $\mathrm{A}$ and $\mathrm{B}$ sites. It is known that $\mathrm{Ni}^{2+}$ and $\mathrm{Cu}^{2+}$ occupy $\mathrm{B}$ sites, although $\mathrm{Fe}^{3+}$ and $\mathrm{Mn}^{2+}$ exist at both $A$ and $B$ sites [11]. When $\mathrm{Mn}^{2+}$ is added at the cost of $\mathrm{Ni}^{2+}$, the iron ions migrate from $A$ site to $B$ sites which increases the iron ion concentration at $B$ sites. For this the magnetic moment of $B$ increases. And net magnetization increases, as magnetic moment of $A$ is constant.

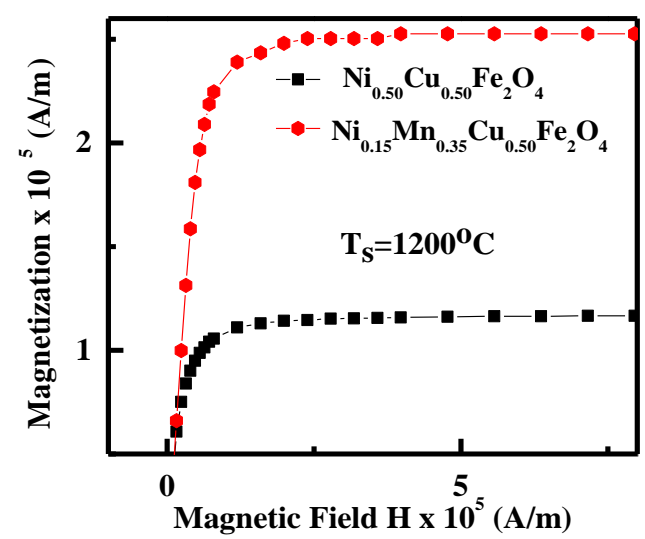

Fig. 6(a). Magnetization as a function of magnetic field for $\mathrm{Ni}_{0.50} \mathrm{Cu}_{0.50} \mathrm{Fe}_{2} \mathrm{O}_{4}$ and $\mathrm{Ni}_{0.15} \mathrm{Mn}_{0.35} \mathrm{Cu}_{0.50} \mathrm{Fe}_{2} \mathrm{O}_{4}$ ferrite sintered at $1200^{\circ} \mathrm{C}$.

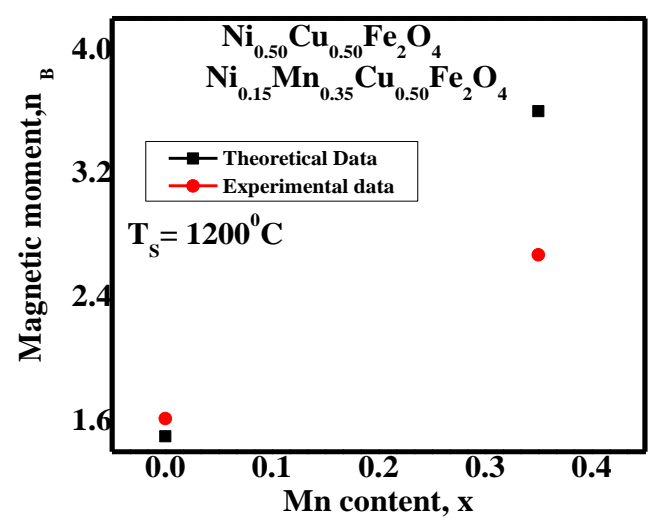

Fig. 6(b). Theoretical and experimental data of magnetic moment, as a function of $\mathrm{Mn}$ content for $\mathrm{Ni}_{0.50} \mathrm{Cu}_{0.50} \mathrm{Fe}_{2} \mathrm{O}_{4}$ and $\mathrm{Ni}_{0.15} \mathrm{Mn}_{0.35} \mathrm{Cu}_{0.50} \mathrm{Fe}_{2} \mathrm{O}_{4}$ ferrite sintered at $1200^{\circ} \mathrm{C}$.

\section{Dielectric and AC Conductivity Measurement}

The dielectric constant decreases rapidly with increasing frequency. The decrease of dielectric constant with increasing frequency is a normal dielectric behavior of spinel ferrites which is shown in Fig.7. The real part of dielectric constant is high at low frequency and slowly decreases, becomes very low at higher frequencies i.e. the frequency independent behavior. Koop's and Maxwell-Wagner polarization theory explained the dielectric dispersion curve.

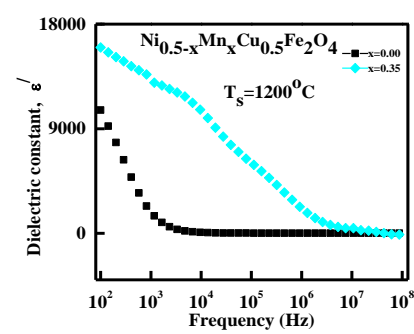

Fig.7(a).Dielectric constant as a function of frequency

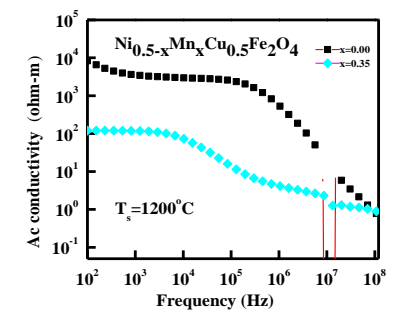

Fig.7(b).Ac conductivity as a function of frequency
The ac resistivity decreases with the increases of frequency and also $\mathrm{Mn}$ doping. This conduction mechanism in the ferrites can be explained on the basis of hopping of charge carriers.
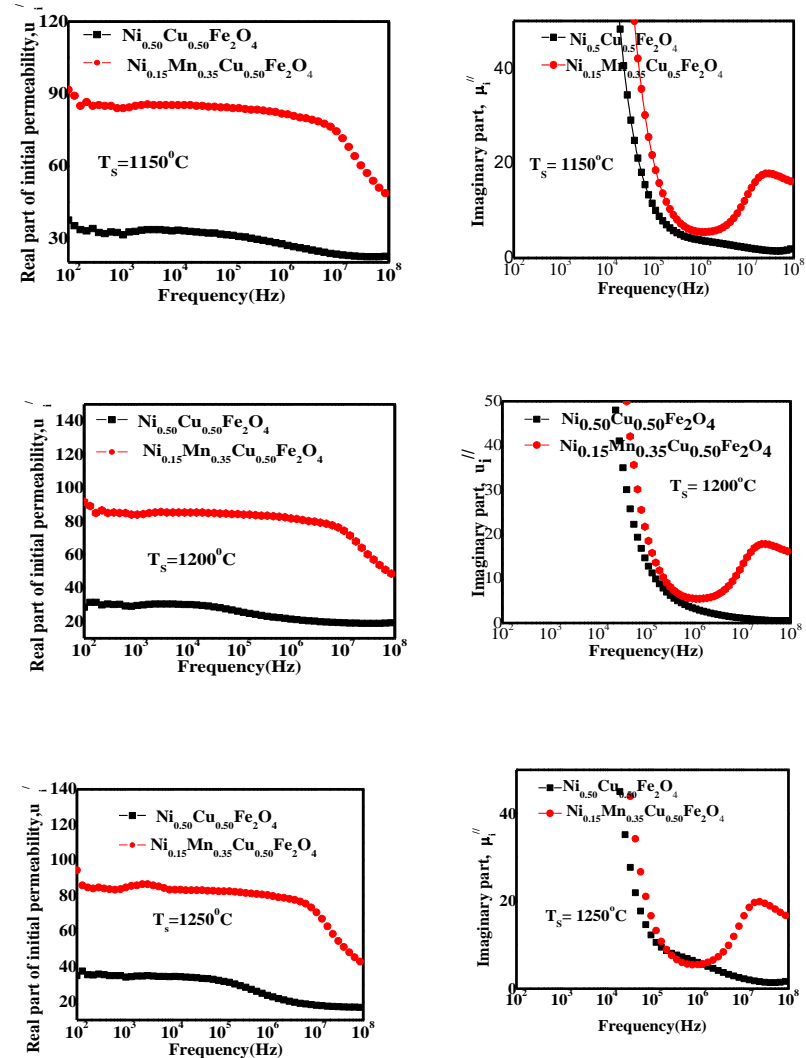

Fig. 8(a, b). The real and imaginary part of complex initial permeability spectra for $\mathrm{Ni}_{0.50} \mathrm{Cu}_{0.50} \mathrm{Fe}_{2} \mathrm{O}_{4}$ and $\mathrm{Ni}_{0.15} \mathrm{Mn}_{0.35} \mathrm{Cu}_{0.50} \mathrm{Fe}_{2} \mathrm{O}_{4}$ sintered at $1150^{\circ} \mathrm{C}$ to $1250^{\circ} \mathrm{C}$.

\section{Complex Initial Permeability}

Fig. 8(a, b) Shows the complex permeability spectra for $\mathrm{Ni}_{0.50} \mathrm{Cu}_{0.50} \mathrm{Fe}_{2} \mathrm{O}_{4}$ and $\mathrm{Ni}_{0.15} \mathrm{Mn}_{0.35} \mathrm{Cu}_{0.50} \mathrm{Fe}_{2} \mathrm{O}_{4}$ sintered at $1150^{\circ} \mathrm{C}$ to $1250^{\circ} \mathrm{C}$. From this Fig. it is observed that the real and imaginary part of complex permeability increases with increase of $\mathrm{Mn}$ doping. 
The real part of complex permeability increases from 38 to 91 at sintering temperature $1150^{\circ} \mathrm{C}, 34$ to 93 at sintering temperature $1200^{\circ} \mathrm{C}$ and 39 to 96 at sintering temperature $1250^{\circ} \mathrm{C}$. It is also found from Fig.9 that the relative quality factor (RQF) increases with increasing $\mathrm{Mn}$ content, it increases from 347 to 1235 at sintering temperature $1150^{\circ} \mathrm{C}, 702$ to 1237 at sintering temperature $1200^{\circ} \mathrm{C}$ and 221 to 1214 at sintering temperature $1250^{\circ} \mathrm{C}$. On the other hand, relative loss factor decreases with increasing $\mathrm{Mn}$ content. It decreases from 254 to 213 at sintering temperature $1150^{\circ} \mathrm{C}, 308$ to 210 at sintering temperature $1200^{\circ} \mathrm{C}$ and 220 to 155 at sintering temperature $1250^{\circ} \mathrm{C}$. Also, at the increasing of sintering temperatures real part of complex permeability increases. It is 91at sintering temperature $1150^{\circ} \mathrm{C}, 93$ at sintering temperature $1200^{\circ} \mathrm{C}$ and 96 at sintering temperature $1250^{\circ} \mathrm{C}$. On the other hand, relative loss factor decreases with increasing sintering temperatures. It is 213 at sintering temperature $1150^{\circ} \mathrm{C}, 210$ at sintering temperature $1200^{\circ} \mathrm{C}$ and 155 at sintering temperature $1250^{\circ} \mathrm{C}$. The ratio of the loss tangent $(\tan \delta)$ to the initial permeability $\left(\mu_{\mathrm{i}}\right)$, known as the RLF.
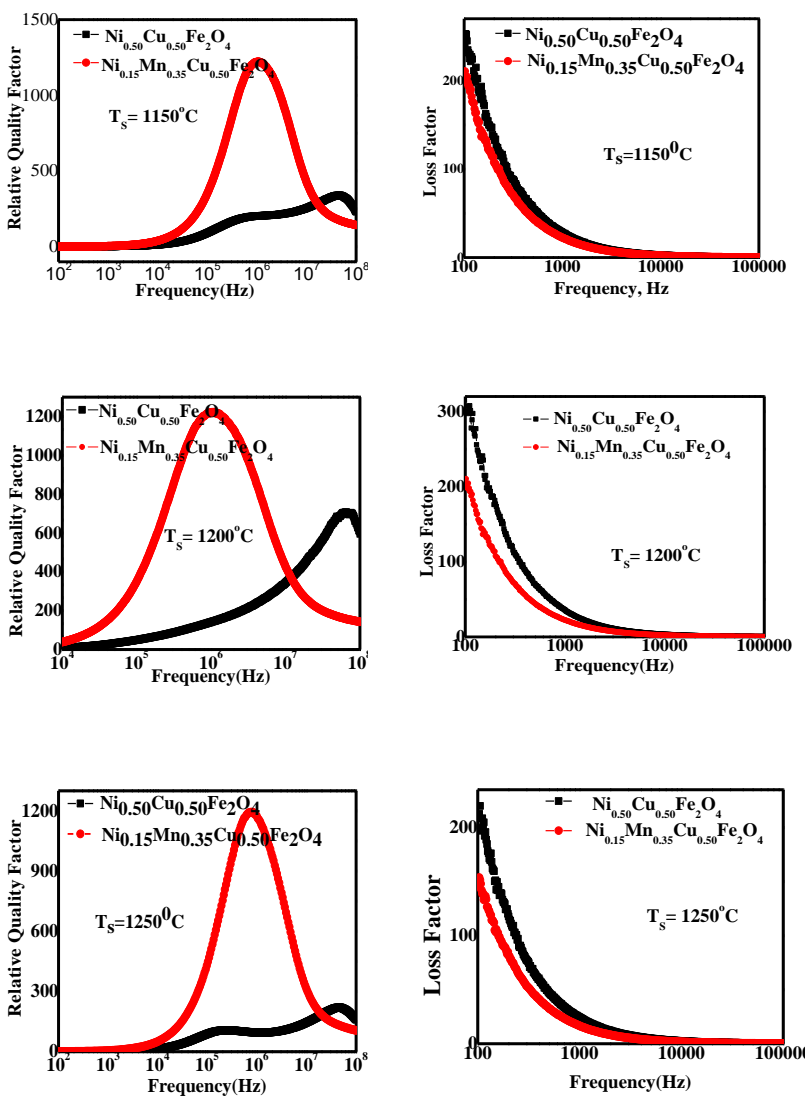

Fig. 9 (a). The RQF for $\mathrm{Ni}_{0.50} \mathrm{Cu}_{0.50} \mathrm{Fe}_{2} \mathrm{O}_{4}$ and $\mathrm{Ni}_{0.15} \mathrm{Mn}_{0.35} \mathrm{Cu}_{0.50} \mathrm{Fe}_{2} \mathrm{O}_{4}$ sintered at $1150^{\circ} \mathrm{C}$ to $1250^{\circ} \mathrm{C}$.
Fig. 9 (b). The RLF for $\mathrm{Ni}_{0.50} \mathrm{Cu}_{0.50} \mathrm{Fe}_{2} \mathrm{O}_{4}$ and $\mathrm{Ni}_{0.15} \mathrm{Mn}_{0.35} \mathrm{Cu}_{0.50} \mathrm{Fe}_{2} \mathrm{O}_{4}$ $1250^{\circ} \mathrm{C}$. sintered at $1150^{\circ} \mathrm{C}$ to
From the permeability study it is found that at the sintering temperature $1250^{\circ} \mathrm{C}$ the real part of complex permeability is the highest and loss factor is the lowest. The $\mu_{i}^{\prime}$ remains constant up to the resonance frequency, $f_{r}$ and for further increase in frequency a sharp fall in $\mu_{i}^{\prime}$. We can say that at the increases of $\mathrm{Mn}$ content grain size increases and the $M_{s}$ also increases with increasing $M n$ content. The permeability of nanocrystalline ferrite is related to two different magnetizing mechanisms: spin rotation and domain wall motion [12-14] which can be described as follows:

$\mu_{i}^{\prime}=1+\chi_{w}+\chi_{\text {spin }}$

where $\chi_{w}$ is the domain wall susceptibility, $\chi_{\text {spin, }}$ is intrinsic rotational susceptibility. $\chi_{w}$ and $\chi_{\text {spin }}$ may be written as:

$\chi_{w}=3 \pi M_{s}^{2} D / 4 \gamma$ and $\chi_{\text {spin }}=2 \pi M_{s}^{2} / K$

where $M_{s}$ saturation magnetization, $K$, the total anisotropy, $\gamma$, the domain wall energy and $D$, the average grain diameter. It is known that bigger grain increases the saturation magnetization and complex permeability. Therefore, in the present study variation of the complex permeability is influenced by its grain size and DC magnetization property. With increase in frequency there is a decreasing trend in permeability. This is because at higher frequencies nonmagnetic impurities between intragranular pores and grains act as pinning points and increasingly hinder the motion of spin and domain walls thereby decreasing their permeability [15].

\section{Conclusion}

Spinel ferrites are widely used in several technological applications i.e. data storage, sensors, transformers, telecommunications, microwave and biomedical applications. Recently, mobile data wireless transmission was draw attention in the electronics industry. The insulating property of ferrites is used in electric motors; they are also used as flat rings for loud speakers and correction magnets for TV. Ferrites are also used in thermal sensing switches which can be used in refrigerators, air conditioners, electronic ovens etc. The combustion method is cheap, low time consuming method in which the precursors are easily available for synthesis of nanoscale materials. In environmental science nano ferrites are used in treating polluted waste water from industry. Here, in the present study nanocrystalline ferrites are successfully synthesized by this method. The XRD patterns of the samples confirmed the formation of spinel structure. From the calcined powder graphs, nano-sized particle nature was found. The lattice constant increases with the increases of $\mathrm{Mn}$ doping. From the optical micrographs at sintering temperature $1200^{\circ} \mathrm{C}$, at the 
increase of $\mathrm{Mn}$, average grain size increases. Due to substitution of $\mathrm{Mn}$ the real part of the complex permeability, relative quality factor, saturation magnetization increases. On the other hand the relative loss factor showed opposite trend.

\section{References}

1. H. Hamdeh, Z. Zia, R. Foehrweiser, J. Appl. Phys.76, 1135 (1994).

2. J. M. Hasting, and L. M. Corliss, Phys. Rev. 102, 460 (1956).

3. Ra'ul Valenzuela, Novel Applications of Ferrites, Hindawi Publishing Corporation Physics Research International Volume, Article ID 591839, 9 pages,. (2012)

4. P M Prithviraj Swamy, S Basavaraja, Arunkumar Lagashetty, N V Srinivas Rao, R Nijagunappa and A Venkataraman,"Synthesis and characterization of zinc ferrite nanoparticles obtained by self-propagating low-temperature combustion method", Bull. Mater. Sci., Vol. 34, No. 7, pp. 1325-1330,.

5. V.V. Parfenov, R.A. Nazipov, Inorg. Mater. 38, 90, (2002) .
6. A. K. M. Akther Hossain, M. Seki, T. Kawai, H. Tabata, J. Appl. Phys. 96, 1273, (2004).

7. A . Verma, T.C .Goel, R. G .Mendiratta, Mater. Sci. Tech. 16, 712 (2000).

8. C. Rath, S. Anand, R. P. Das, K. K. Sahu, S. D. Kulkarni, S. K. Date, N. C. Mishra, J. Appl. Phys. 91, 2211 (2002).

9. R. D. Shannon, Acta crystallogr A 32, 751 (1976).

10. M. Mendelson, I. Ceram, J. Am. Soc. 52(8), 443 (1967).

11. J. Smit and H. P. J. Wijn, Philips Technical Library, Eindhoven, Netherland, 149 (1959).

12. Hu, Jun and Yan, Mi, Journal of Zhejiang University Science B 6,580 (2005).

13. S. T. Mahmud, A. K. M. Akther Hossain, A. K. M. Abdul Hakim, M. Seki, T. Kawai and H. Tabata, J. Magn. Magn. Mater. 305, 269 (2006).

14. T. Tsutaoka, M. Ueshima, T. Tokunaga, T. Nakamura and K. Hatakeyama J. Appl. Phys. 78, 3983 (1995).

15. A. Globus, Thesis, Univ. of Paris, Paris, France(1963). 